\title{
ANALISIS SIKAP MASYARAKAT TERHADAP PENGHAPUSAN LAYANAN TRANSPORTASI UMUM DI JAKARTA
}

\author{
Muhammad Luthfi Wibowo ${ }^{1}$, Leksmono Suryo Putranto ${ }^{2}$ \\ ${ }^{1}$ Program Studi Sarjana Teknik Sipil, Universitas Tarumanagara, Jl.Letjen S. Parman No.1 Jakarta \\ Email: luthfiwibowo@ rocketmail.com \\ ${ }^{2}$ Program Studi Sarjana Teknik Sipil, Universitas Tarumanagara, Jl.Letjen S. Parman No.1 Jakarta \\ Email:lexy_putranto@yahoo.co.id
}

\begin{abstract}
ABSTRAK
Transportasi umum memainkan peranan penting dalam mobilitas di perkotaan. Gangguan pada transportasi umum yang menghapus semua layanan dapat berdampak besar terhadap perjalanan dan meningkatkan kemacetan lalu lintas. Skripsi ini meneliti reaksi perilaku pengguna transportasi umum di Jakarta terhadap penghapusan layanan transportasi umum. Pengumpulan data dilakukan menggunakan kuesioner terhadap responden pria dan wanita yang melakukan perjalanan dengan tujuan pendidikan maupun pekerjaan. Kuesioner dibagikan kepada 100 responden dengan metode langsung dan metode online masing-masing 50 responden. Dari 100 responden, $44 \%$ akan beralih dari transportasi umum ke ojek online, $37 \%$ akan beralih ke motor pribadi, dan $9 \%$ akan beralih ke mobil pribadi. Pergeseran moda ke kendaraan pribadi akan berkontribusi langsung dengan peningkatan kemacetan.
\end{abstract}

Kata kunci: pergeseran moda, kemacetan perjalanan, transportasi umum.

\section{PENDAHULUAN}

\section{Latar Belakang}

Transportasi umum menyediakan berbagai manfaat untuk sistem transportasi modern, seperti mengurangi lalu lintas kemacetan, meningkatkan keselamatan lalu lintas kemacetan, mengurangi polusi udara dan polusi suara, dan meningkatkan aksesibilitas, terutama untuk non-driver (Litman, 2015). Namun, gangguan terhadap transportasi umum dapat terjadi karena berbagai faktor seperti kerusakan kendaraan, listrik padam dan pemogokan tenaga (Pnevmatikou, 2015).

Pemogokan transportasi umum telah terjadi di beberapa kota besar contohnya di Jakarta. Pada tahun 2016, sistem transportasi umum Jakarta mengalami pemogokan angkutan umum mobil, taksi konvensional, bus kota, dan bajai yang ditandai pencegatan mobil yang dicurigai taksi online. Mereka memprotes beroperasinya taksi-taksi berbasis aplikasi, yang dinilai menyaingi profesi mereka secara tidak adil. Serangan ini secara alami mempengaruhi pengguna transportasi umum sampai batas tertentu, terutama dalam rencana perjalanan mereka sehari-hari.

Dalam hal ini kita bisa melihat bahwa, masih banyak masyarakat yang membutuhkan transportasi umum untuk perjalanan mereka sehari-hari, baik untuk tujuan perjalanan yang berhubungan dengan pendidikan maupun yang berhubungan dengan pekerjaan atau lainnya.

\section{Batasan Masalah}

Berdasarkan identifikasi masalah tesebut, tidak semua permasalahan akan diteliti. Hal ini untuk menghindari berbagai persepsi dan meluasnya permasalahan yang muncul berkaitan dengan penelitian ini. Penelitian ini akan dibatasi pada lingkup pembahasan masalah transportasi umum yang ditemui masyarakat sehubungan dengan partisipasi penggunaan transportasi umum mereka. Responden pada penelitian ini dibatasi untuk laki-laki dan perempuan yang belum bekerja, sudah bekerja dan atau berumah tangga.

\section{Rumusan Masalah}

Berdasarkan uraian latar belakang, identifikasi masalah serta pembatasan masalah diatas, maka dapat dirumuskan masalah penelitiannya yaitu :

1. Apakah transportasi umum menjadi satu-satunya pilihan masyarakat di wilayah Jabodetabek yang tidak memiliki kendaraan pribadi?

2. Bagaimana layanan transportasi umum memfasilitasi akses masyarakat terhadap tujuan perjalanan? 
3. Bagaimana persepsi masyarakat tentang kinerja Transportasi Umum di Jabodetabek?

4. Apakah masyarakat lebih memilih menggunakan kendaraan pribadi dibanding transportasi umum?

\section{Tujuan Penelitian}

1. Mengetahui pilihan masyarakat di wilayah Jabodetabek yang tidak memiliki kendaraan pribadi terhadap transportasi umum.

2. Mengetahui layanan transportasi umum memfasilitasi akses masyarakat terhadap tujuan perjalanan

3. Mengetahui persepsi masyarakat tentang kinerja transportasi umum di Jabodetabek.

4. Mengetahui pilihan penggunaan masyarakat terhadap kendaraan pribadi dan transportasi umum.

\section{TINJAUAN PUSTAKA}

Di negara-negara berkembang, permasalahan kemacetan sendiri disebabkan oleh banyak hal. Pendapatan rendah, urbanisasi yang sangat cepat, terbatasnya sumber daya, khususnya dana, kualitas dan kuantitas data yang berkaitan dengan transportasi, kualitas sumber daya manusia, tingkat disiplin yang rendah, dan lemahnya sistem perencanaan dan kontrol membuat permasalahan transportasi menjadi semakin parah (Tamin: 2000).

Minat warga DKI Jakarta untuk menggunakan transportasi umum masih tergolong rendah. Hal ini terlihat dari hasil kajian Badan Pengelola Transportasi Jabodetabek, yang menyebutkan, dari total 47,5 juta perjalanan yang terjadi di Jabodetabek pada 2015 lalu, baru 24 persen pengguna jalan yang memutuskan untuk menggunakan moda angkutan umum darat, seperti bus Transjakarta dan atau commuter line. Dengan rincian, pengguna bus Transjakarta sebanyak 326.500 per hari, dan commuter line Jabodetabek sebanyak 759.564 per hari (Abubakar: 2017).

Jumlah tersebut berbanding terbalik dengan jumlah pengguna kendaraan bermotor pribadi. Data Dinas Perhubungan dan Transportasi DKI Jakarta pada 2015 menunjukkan, jumlah kendaraan bermotor pribadi di DKI Jakarta mencapai 7.979.833 unit. Dengan rata-rata pertumbuhan hingga 8,12 persen per tahun. Tingginya pertumbuhan kepemilikan kendaraan bermotor pribadi dan rendahnya minat warga untuk menggunakan transportasi umum inilah yang menjadi salah satu alasan kemacetan di ibu kota sulit diatasi. Belum lagi kendala lain seperti belum sterilnya jalur bus Transjakarta, banyaknya rute angkutan umum regular yang berhimpitan dengan angkutan massal seperti dengan Transjakarta, serta belum jelasnya pelaksanaan dari electronic registration and identification (ERI), electronic law enforcement (ELE), dan electronic road pricing (ERP).

Upaya mengurai macet dengan mengalihkan pengguna kendaraan pribadi ke kendaraan umum semakin sulit lantaran besarnya biaya yang harus dikeluarkan warga Jakarta untuk berpergian dengan kendaraan umum. Rata-rata warga Jakarta saat ini mengeluarkan 20 hingga 35 persen penghasilannya untuk berpergian dengan transportasi umum, sejumlah permasalahan itu menjadi tantangan besar Pemerintah Provinsi DKI Jakarta yang tengah menargetkan pengguna angkutan umum bisa mencapai 40 persen pada 2019 mendatang (Abubakar: 2017).

\section{Faktor-Faktor Yang Mempengaruhi Pemilihan Moda Transportasi}

Moda Split adalah salah satu bagian dari proses Travel Demand Modelling yang memegang peranan penting dari angkutan umum dalam kebijakan transportasi. Hal ini terkait dengan penyediaan sarana angkutan dan juga prasarana jalan yang diperlukan untuk terjadinya proses pergerakan dengan tersedianya moda yang ada.

Pemilihan moda (moda split) dapat didefinisikan sebagai pembagian dari perjalanan yang dilakukan oleh pelaku perjalanan kedalam moda yang tersedia dengan berbagai faktor yang mempengaruhi. Sedangkan model pemilihan moda merupakan model yang menggambarkan perilaku pelaku perjalanan dalam memilih moda yang digunakan. Faktor-faktor yang mendasari pemilihan moda akan sangat bervariasi antara individu yang satu dengan yang lain.

Manusia sebagai pelaku perjalanan selalu memilih transportasi yang paling menguntungkan, baik dilihat dari segi ekonomi, efisiensi maupun tingkat pelayanan yang diinginkan. Dalam keadaan tertentu, pemakai alat transportasi dalam melakukan perjalanan dapat memilih dari beberapa macam alat transportasi yang tersedia.

Faktor-faktor yang mempengaruhi dalam alat transportasi diantaranya adalah:

1. Karakteristik dari pelaku perjalanan, meliputi antara lain: pekerjaan, usia, pendapatan, pendidikan.

2. Karakteristik dari perjalanan, meliputi antara lain: maksud dan tujuan perjalanan, kapan perjalanan dilakukan.

3. Karakteristik fasilitas transportasi, meliputi antara lain: kenyamanan keamanan, kehandalan. 


\section{Transportasi Umum}

Transportasi umum adalah sebuah layanan angkutan penumpang bersama yang tersedia untuk digunakan oleh masyarakat umum, berbeda dengan moda transportasi seperti taksi, bus sewa, dan perusahaan jaringan transportasi, yang tidak dapat diakses oleh masyarakat umum tanpa adanya pemesanan secara mandiri.

Transportasi merupakan proses kegiatan memindahkan barang dan orang dari satu tempat ke tempat yang lain (Morlok: 1985), sehingga transportasi adalah bukan tujuan melainkan sarana untuk mencapai tujuan guna menanggulangi kesenjangan jarak dan waktu (Nasution: 1996).

Angkutan umum berfungsi melayani pergerakan orang dan barang sehingga kebijaksanaan yang menyangkut sistem perangkutan tidak dapat mengabaikan perannya yang penting itu (Warpani: 1990). Angkutan umum antar kota didominasi oleh bus antarkota, kereta api, dan kereta antarkota. Jaringan kereta berkecepatan tinggi sedang dikembangkan di banyak belahan dunia. Sebagian besar sistem transportasi umum berjalan di sepanjang rute tetap dengan titik pemberhentian dengan jadwal yang telah diatur sebelumnya. Taksi berbagi menawarkan layanan berdasarkan-permintaan di banyak bagian dunia, dan beberapa layanan akan menunggu sampai kendaraan penuh sebelum taksi tersebut berangkat. Paratransit terkadang digunakan di daerah dengan permintaan rendah dan orangorang yang membutuhkan layanan dari pintu ke pintu. Direktorat Jendral Perhubungan Darat, Departemen Perhubungan RI memberikan batasan efisien dan efektif sebagai berikut :

1. Kapasitas mencukupi, prasarana dan sarana cukup tersedia untuk memenuhi kebutuhan pengguna jasa;

2. Terpadu, antarmoda dan intramoda dalam jaringan pelayanan;

3. Tertib, menyelenggarakan angkutan yang sesuai dangan peraturan perundang-undangan dan norma yang berlaku di masyarakat;

4. Tepat dan teratur, terwujudnya penyelenggaraan angkutan yang andal, sesuai dengan jadwal dan ada kepastian;

5. Cepat dan lancar, menyelenggarakan layanan angkutan dalam waktu singkat, indikatornya antara lain kecepatan arus per satuan waktu;

6. Aman dan nyaman, dalam arti selamat terhindar dari kecelakaan, bebas dari gangguan eksternal, terwujud ketenangan dan kenikmatan dalam perjalanan.

Efisien mengandung arti :

1. Biaya terjangkau, penyediaan layanan angkutan sesuai dengan tingkat daya beli masyarakat pada umumnya dengan tetap memperhatikan kelangsungan hidup pengusaha pelayanan jasa angkutan;

2. Beban publik rendah, pengorbanan yang harus ditanggung oleh masyarakat sebagai konsekuensi pengoperasian sistem perangkutan harus minimal;

3. Kemanfaatan tinggi, merupakan tingkat penggunaan kapasitas sistem perangkutan yang dapat dinyatakan dalam indikator tingkat muatan penumpang maupun barang, tingkat penggunaan prasarana dan sarana.

Pada saat ini sebagian besar pemakai angkutan umum masih mengalami beberapa aspek negatif sistem angkutan umum jalan raya (Tamin: 2000), yaitu :

1. Tidak adanya jadwal yang tetap;

2. Pola rute yang memaksa terjadinya transfer;

3. Kelebihan penumpang pada saat jam sibuk;

4. Cara mengemudikan kendaraan yang sembarangan dan membahayakan keselamatan;

5. Kondisi internal dan eksternal yang buruk.

\section{METODOLOGI PENELITIAN}

\section{Metode pengumpulan data}

Metode yang digunakan untuk mengumpulkan data adalah dengan metode survei melalui kuesioner. Dengan melakukan pengelompokan terhadap pengguna layanan transportasi umum dan pengelompokan sikap pengguna yang berpindah ke moda transportasi yang lain saat layanan transportasi umum dihapus. Dalam penelitian ini diwawancarai 100 responden, dengan proporsi 50 responden diwawancarai secara langsung dan 50 responden secara online. Mereka berada pada segmentasi usia 18 tahun ke atas dan responden menggunakan transportasi umum dan atau kendaraan pribadi. Survey dilakukan secara umum di wilayah Jabodetabek.

\section{Metode analisis data}

Untuk menguji hipotesis, maka analisis yang digunakan pada penelitian ini adalah menggunakan program SPSS untuk mendapat nilai frekuensi (\%) pada setiap variabel dan menguji validitas dan reliabilitas dari kuesioner. 


\section{ANALISIS DATA}

Rangkuman jawaban responden untuk tiap kelompok sikap dapat dilihat pada tabel 1. L menunjukan data kuesioner langsung. O menunjukan data kuesioner online. G menunjukan data kuesioner gabungan. Pada tabel-tabel tersebut disajikan jumlah data, nilai minimum, nilai maksimum, dan nilai rataan.

Tabel 1. Jumlah Data, Nilai Minimal, Nilai Maksimal dan Rataan Dari Hasil Pelayanan Transportasi Umum

\begin{tabular}{|c|c|c|c|c|c|c|}
\hline No & Indikator & Tipe & $\mathbf{N}$ & Minimal & Maksimal & Rataan \\
\hline \multirow{3}{*}{1} & \multirow{3}{*}{$\begin{array}{l}\text { Apakah anda puas terhadap } \\
\text { penggunaan Transportasi Umum }\end{array}$} & $\mathrm{L}$ & 50 & 1 & 4 & 2,38 \\
\hline & & $\mathrm{O}$ & 50 & 1 & 4 & 2,34 \\
\hline & & $\mathrm{G}$ & 100 & 1 & 4 & 2,36 \\
\hline \multirow{3}{*}{2} & \multirow{3}{*}{$\begin{array}{c}\text { Bagaimana kondisi dan kelengkapan } \\
\text { sarana dan prasarana Transportasi } \\
\text { Umum }\end{array}$} & $\mathrm{L}$ & 50 & 1 & 4 & 2,62 \\
\hline & & $\mathrm{O}$ & 50 & 1 & 5 & 2,6 \\
\hline & & $\bar{G}$ & 100 & 1 & 5 & 2,61 \\
\hline \multirow{3}{*}{3} & \multirow{3}{*}{$\begin{array}{l}\text { Bagaimana pelayanan awak } \\
\text { transportasi umum yang anda } \\
\text { gunakan }\end{array}$} & $\mathrm{L}$ & 50 & 1 & 5 & 2,5 \\
\hline & & $\mathrm{O}$ & 50 & 1 & 4 & 2,48 \\
\hline & & $G$ & 100 & 1 & 5 & 2,49 \\
\hline \multirow{3}{*}{4} & \multirow{3}{*}{$\begin{array}{c}\text { Bagaimana dengan waktu tempuh } \\
\text { Transportasi Umum yang anda } \\
\text { gunakan }\end{array}$} & $\mathrm{L}$ & 50 & 1 & 5 & 2,8 \\
\hline & & $\mathrm{O}$ & 50 & 1 & 5 & 2,58 \\
\hline & & $\mathrm{G}$ & 100 & 1 & 5 & 2,69 \\
\hline \multirow{3}{*}{5} & \multirow{3}{*}{$\begin{array}{l}\text { Bagaimana dengan tingkat keamanan } \\
\text { menggunakan transportasi umum }\end{array}$} & $\mathrm{L}$ & 50 & 1 & 5 & 2,7 \\
\hline & & $\mathrm{O}$ & 50 & 1 & 5 & 2,66 \\
\hline & & $\mathrm{G}$ & 100 & 1 & 5 & 2,68 \\
\hline \multirow{3}{*}{6} & \multirow{3}{*}{$\begin{array}{l}\text { Bagaimana dengan tingkat } \\
\text { keselamatan menggunakan } \\
\text { transportasi umum }\end{array}$} & $\mathrm{L}$ & 50 & 1 & 5 & 2,22 \\
\hline & & $\mathrm{O}$ & 50 & 1 & 4 & 2,56 \\
\hline & & $G$ & 100 & 1 & 5 & 2,39 \\
\hline \multirow{3}{*}{7} & \multirow{3}{*}{$\begin{array}{l}\text { Bagaimana dengan tarif yang } \\
\text { diberlakukan penyedia layanan } \\
\text { transportasi umum }\end{array}$} & $\mathrm{L}$ & 50 & 1 & 3 & 1,66 \\
\hline & & $\mathrm{O}$ & 50 & 1 & 3 & 1,98 \\
\hline & & $G$ & 100 & 1 & 3 & 1,82 \\
\hline
\end{tabular}

Dari hasil pada tabel 1 diatas, kita dapat melihat bahwa indikator memiliki skor yang bervariansi, artinya bahwa responden untuk kategori puas terhadap penggunaan transportasi umum, pelayanan awak transportasi umum, tingkat keselamatan transportasi umum, dan tarif transportasi umum memliki skor dibawah 2,5 yang menunujukkan kearah positif yaitu puas. Sedangkan untuk kategori kondisi kelengkapan sarana dan prasarana transportasi umum, waktu tempuh transportasi umum, dan tingkat keamanan transportasi umum memiliki skor diatas 2,5 yang menunjukkan kearah negatif yaitu kurang puas.

Mengingat skala yang digunakan adalah 1-5 yang merupakan frekuensi puas atau tidaknya seseorang terhadap pelayanan transportasi umum, maka semakin kecil skalanya semakin puas seseorang terhadap transportasi umum kebalikannya jika skalanya semakin besar maka semakin tidak puas seseorang tersebut terhadap transportasi umum. 


\section{ANALISIS SELISIH RATAAN}

Dari tabel 2 terlihat bahwa ada variabel yang signifikan pada angka 0,00 pada variabel tingkat keselamatan menggunakan transportasi umum. Ditunjukkan dengan responden perempuan yang cenderung memberikan penilaian lebih buruk terhadap keselamatan menggunakan transportasi umum. Disimpulkan bahwa perempuan merasa tidak selamat menggunakan tranportasi umum dapat dikarenakan sopir yang mengendarai secara ugal-ugalan ataupun suka menerobos lampu merah yang membuat responden perempuan merasa tidak selamat.

Tabel 2. Uji Selisih Rataan Berdasarkan Jenis Kelamin Responden

\begin{tabular}{|c|c|c|c|c|c|}
\hline $\begin{array}{c}\text { Kepuasan Terhadap Transportasi } \\
\text { Umum }\end{array}$ & Laki-laki & Perempuan & $\begin{array}{c}\text { Selisih } \\
\text { Rataan }\end{array}$ & $\begin{array}{c}\text { Tingkat } \\
\text { Signifikan }\end{array}$ & $\begin{array}{c}\text { Signifikan ? } \\
\text { (Ya/Tidak) }\end{array}$ \\
\hline $\mathrm{N}$ & 36 & 64 & \multicolumn{2}{|c|}{} \\
\hline $\begin{array}{c}\text { Puas terhadap penggunaan Transportasi } \\
\text { Umum }\end{array}$ & 2,22 & 2,44 & $-0,22$ & 0,17 & Tidak \\
\hline $\begin{array}{c}\text { Kondisi dan kelengkapan sarana dan } \\
\text { prasarana Transportasi Umum }\end{array}$ & 2,47 & 2,69 & $-0,22$ & 0,21 & Tidak \\
\hline $\begin{array}{c}\text { Pelayanan awak transportasi umum yang } \\
\text { anda gunakan }\end{array}$ & 2,36 & 2,56 & $-0,20$ & 0,22 & Tidak \\
\hline $\begin{array}{c}\text { Waktu tempuh Transportasi Umum yang } \\
\text { anda gunakan }\end{array}$ & 2,67 & 2,70 & $-0,04$ & 0,87 & Tidak \\
\hline
\end{tabular}

\begin{tabular}{|c|c|c|c|c|c|}
\hline $\begin{array}{c}\text { Kepuasan Terhadap Transportasi } \\
\text { Umum }\end{array}$ & Laki-laki & Perempuan & $\begin{array}{l}\text { Selisih } \\
\text { Rataan }\end{array}$ & $\begin{array}{c}\text { Tingkat } \\
\text { Signifikan }\end{array}$ & $\begin{array}{r}\text { Signifikan ? } \\
\text { (Ya/Tidak) }\end{array}$ \\
\hline $\mathrm{N}$ & 36 & 64 & & & \\
\hline $\begin{array}{c}\text { Tingkat keamanan menggunakan } \\
\text { transportasi umum }\end{array}$ & 2,47 & 2,80 & $-0,33$ & 0,09 & Tidak \\
\hline $\begin{array}{c}\text { Tingkat keselamatan menggunakan } \\
\text { transportasi umum }\end{array}$ & 2,08 & 2,56 & $-0,48$ & 0,00 & $\mathrm{Ya}$ \\
\hline Tarif layanan transportasi umum & 1,72 & 1,88 & $-0,15$ & 0,34 & Tidak \\
\hline Rata-rata & 2,29 & 2,52 & $-0,23$ & 0,06 & Tidak \\
\hline
\end{tabular}

\section{KESIMPULAN}

Berdasarkan hasil kuesioner analisis sikap masyarakat terhadap penghapusan layanan transportasi umum di Jakarta maka dapat diambil kesimpulan sebagai berikut:

1. Moda transportasi yang memenuhi pilihan kebutuhan masyarakat apabila transportasi umum dihapuskan yaitu motor pribadi, mobil pribadi, ojek online, dan taksi online.

2. Sebagian besar responden lebih memilih menggunakan ojek online apabila layanan transportasi umum dihapuskan.

3. Skor rataan terkecil yang ditunjukan oleh responden ada pada variabel tarif yang diberlakukan penyedia layanan transportasi umum, yang menunjukkan kepuasan responden terhadap tarif yang terjangkau. 
4. Responden tidak puas dengan tingkat keamanan menggunakan transportasi umum, karena masih banyaknya pelaku kejahatan yang melakukan aksinya di dalam transportasi umum.

5. Responden yang berprofesi sebagai mahasiswa yang bertujuan melakukan perjalanan untuk pendidikan lebih cenderung memilih menggunakan transportasi umum dibandingkan kendaraan pribadi, dikarenakan tarif transportasi umum yang jauh lebih murah dibanding kendaraan pribadi.

6. Responden yang tidak memiliki SIM memberikan penilaian lebih tidak puas dibanding yang memiliki SIM terhadap transportasi umum, dan mereka yang tidak puas adalah pengguna non Transjakarta.

\section{DAFTAR PUSTAKA}

Abubakar, I. 2017. "Pengguna Transportasi Umum di Jakarta Masih rendah." Diakses pada tanggal 29 Februari 2018 dan tersedia di: www.cnnindonesia.com/nasional/20170523091500-20-216597/pengguna-transportasiumum-di-jakarta-masih-rendah.

Litman, T., 2015. Evaluating Public Transit Benefits and Costs. Victoria Transport Policy Institute, Victoria, British Columbia, Canada.

Morlok, E.K. 1998. Pengantar Tehnik dan Perencanaan Transportasi. Jakarta : Erlangga.

Nasution, A. 1996. Menajemen Transportasi. Jakarta : Ghalia Indonesia.

Pnevmatikou, A.M., Karlaftis, M.G., Kepaptsoglou, K., 2015. Metro service disruptions: how do people choose to travel? Transportation 42 (6), 933-949.

Tamin, Ofyar, Z. 2000. Perencanaan dan Permodelan Transportasi. Bandung, Indonesia: Penerbit ITB

Warpani. S. 1990. Merencanakan Sistem Pengangkutan. Bandung : ITB.

Warpani, S. 2002. Pengelolaan Lalu Lintas dan Angkutan Jalan. Bandung, Indonesia: Penerbit ITB. 